\title{
Teaching NeuroImages: Isolated mammillary body infarction presenting with memory impairment
}

Kang Min Park, MD, Bong Ju Lee, MD, Tae Hyung Kim, Chi Woong Mun, PhD, and Sung Eun Kim, MD Neurology ${ }^{\circledR}$ 2018;90:e1093-e1094. doi:10.1212/WNL.0000000000005178
Correspondence

Dr. Kim

epidoc@inje.ac.kr

Figure 1 Brain MRI

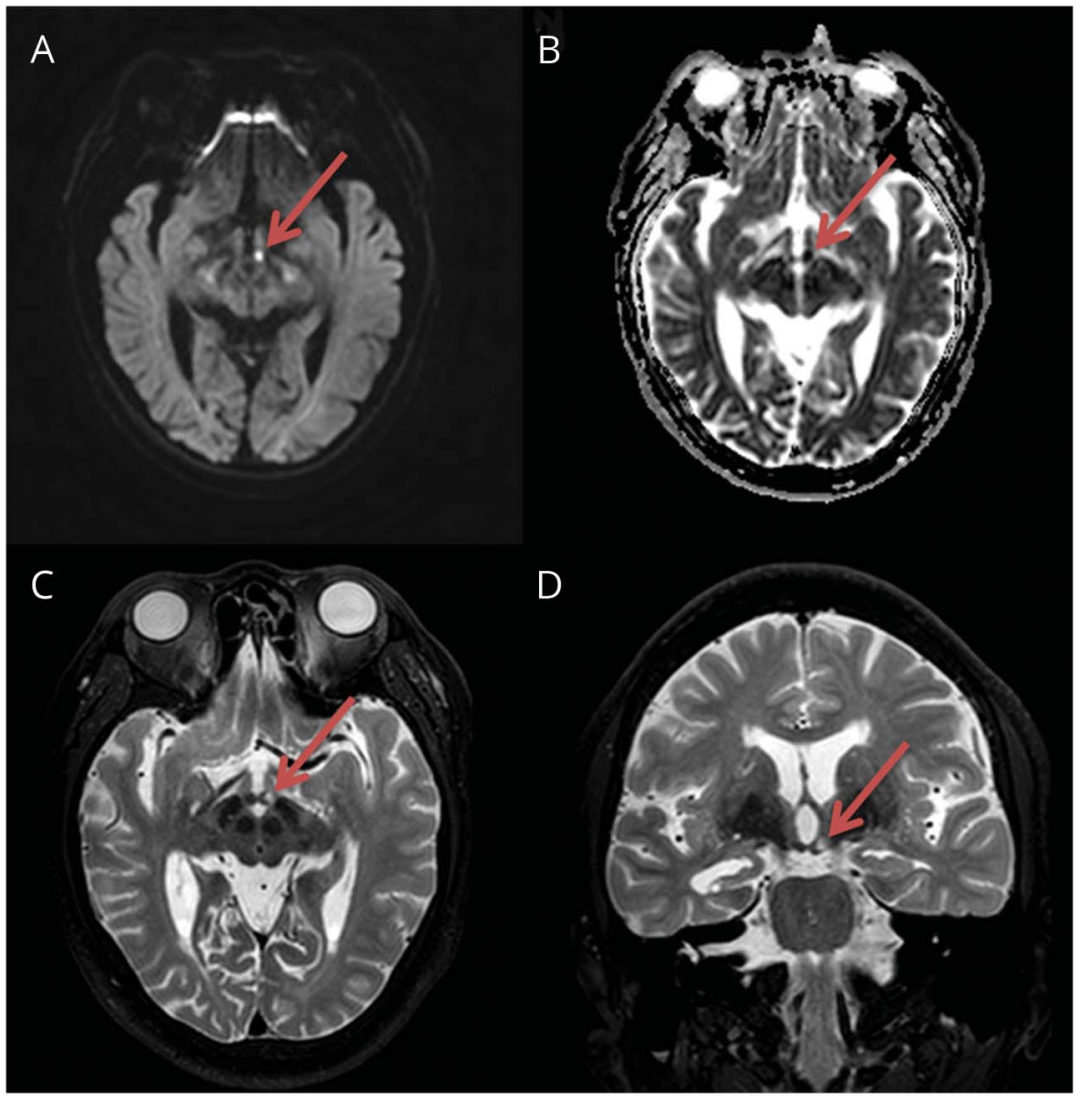

(A) Diffusion-weighted, (B) apparent diffusion coefficient, and (C, D) T2-weighted images show an ischemic infarct in the left mammillary body (arrows).
A right-handed 68-year-old man presented with acute-onset memory impairment. Before the event, he was doing well in his daily life. He had a history of hypertension. On the Seoul Neuropsychological Screening Battery, his verbal memory functions exhibited significant impairments (31.82 percentile for immediate recall, 1.09 percentile for delayed recall, and 2.22 percentile for delayed copy). A brain MRI revealed an acute infarction in the left mammillary body (figure 1), and CT angiography revealed focal stenosis of the bilateral posterior cerebral arteries (figure 2).

\section{MORE ONLINE}

\section{$\rightarrow$ Teaching slides:}

links.lww.com/WNL/A262

From the Departments of Neurology (K.M.P., S.E.K.) and Psychiatry (B.J.L.), Haeundae Paik Hospital, Inje University College of Medicine, Busan; and School of Biomedical Engineering/U-HARC (T.H.K., C.W.M.) and Department of Health Science and Technology (C.W.M.), Inje University, Gimhae, Korea.

Go to Neurology.org/N for full disclosures. Funding information and disclosures deemed relevant by the authors, if any, are provided at the end of the article. 
Figure 2 Brain CT angiography

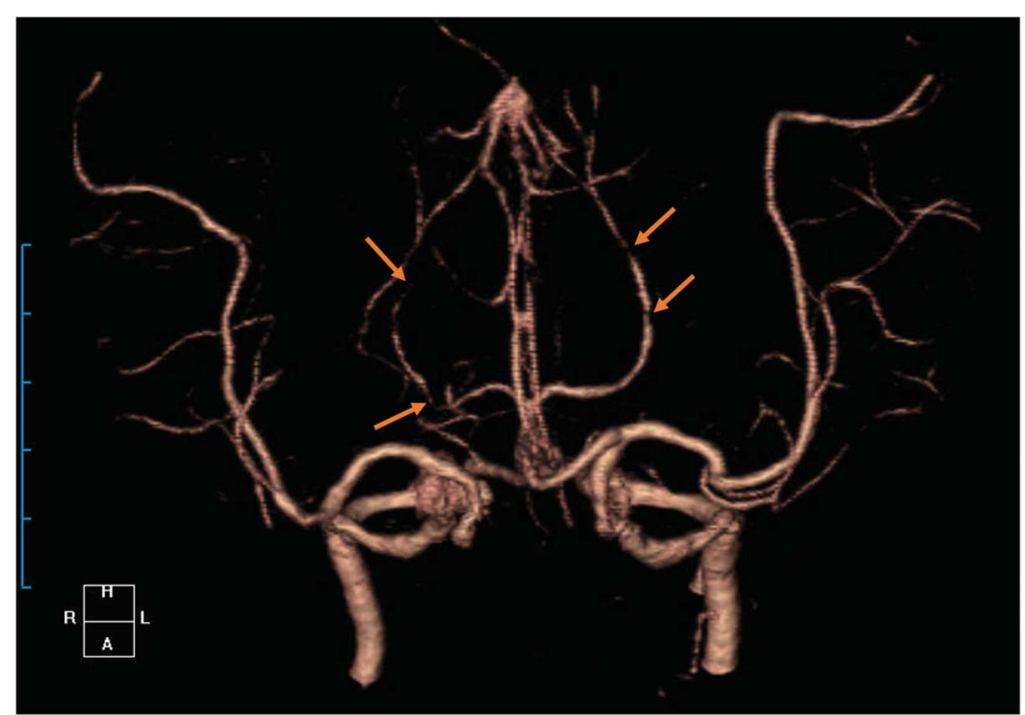

Focal stenosis of the bilateral posterior cerebral arteries (arrows).

The mammillary bodies are part of the Papez circuit, which is involved in memory consolidation and emotional control. ${ }^{1}$

\section{Author contributions}

Sung Eun Kim: design or conceptualization of the study. Bong Ju Lee: interpretation of the neuropsychological data. Tae Hyung Kim and Chi Woong Mun: interpretation of the radiologic data. Kang Min Park: drafting the manuscript.

\section{Study funding}

No targeted funding reported.

\section{Disclosure}

The authors report no disclosures relevant to the manuscript. Go to Neurology.org/N for full disclosures.

\section{Reference}

1. Vann SD, Nelson AJ. The mammillary bodies and memory: more than a hippocampal relay. Prog Brain Res 2015;219:163-185. 


\section{Neurology}

\section{Teaching NeuroImages: Isolated mammillary body infarction presenting with memory impairment}

Kang Min Park, Bong Ju Lee, Tae Hyung Kim, et al.

Neurology 2018;90; 1093-e1094

DOI 10.1212/WNL.0000000000005178

This information is current as of March 19, 2018

\section{Updated Information \&} Services

References

Subspecialty Collections

Permissions \& Licensing

Reprints including high resolution figures, can be found at: http://n.neurology.org/content/90/12/e1093.full

This article cites 1 articles, 0 of which you can access for free at: http://n.neurology.org/content/90/12/e1093.full\#ref-list-1

This article, along with others on similar topics, appears in the following collection(s):

\section{All Cerebrovascular disease/Stroke}

http://n.neurology.org/cgi/collection/all_cerebrovascular_disease_strok e

\section{Infarction}

http://n.neurology.org/cgi/collection/infarction

MRI

http://n.neurology.org/cgi/collection/mri

Information about reproducing this article in parts (figures,tables) or in its entirety can be found online at:

http://www.neurology.org/about/about_the_journal\#permissions

Information about ordering reprints can be found online:

http://n.neurology.org/subscribers/advertise

Neurology ${ }^{\circledR}$ is the official journal of the American Academy of Neurology. Published continuously since 1951, it is now a weekly with 48 issues per year. Copyright @ 2018 American Academy of Neurology. All rights reserved. Print ISSN: 0028-3878. Online ISSN: 1526-632X.

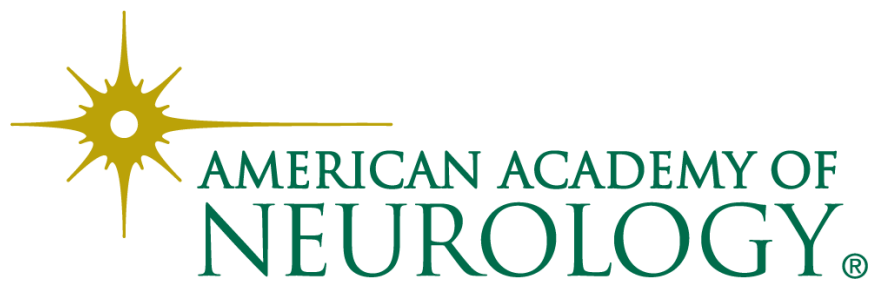

